\title{
Stem Cutting Propagation of Big Sagebrush (Artemisia tridentata Nutt.)
}

\author{
EDUARDO ALVAREZ-CORDERO AND C.M. MCKELL
}

Abstract

Vegetative propagation of big sagebrush (Artemisia tridentata Nutt.) is often desirable to preserve valuable characteristics of ecotypes for use in disturbed site rehabilitation and range research. Previous research is not clear with regard to procedures for sagebrush propagation.

Three experiments were designed to define the influence of synthetic auxin rates, plant dormancy and individual source plants on rooting performance of big sagebrush stem cuttings. Cuttings obtained in the winter during plant dormancy showed greater rooting activity than those collected from actively growing plants. Synthetic auxin, Indolebutyric acid (IBA) treatment, increased root formation as a function of increased auxin concentration but was unable to overcome factors causing seasonal dormancy in cuttings. Source plants varied in the rootability of cuttings. Care should be exercised in selecting only plants that have a high capability for rooting of cuttings.

Big sagebrush (Artemisia tridentata Nutt.) is one of the most important shrubs in the western United States because of its wide distribution and value in providing habitat and food for domesticated and wild animal species. The many ecotypes of big sagebrush are adapted to a variety of sites, thus making it desirable for disturbed site rehabilitation. A method for asexual propagation of big sagebrush is needed to permit direct reproduction of promising ecotypes. This would avoid the delay inherent in breeding and field-testing programs.

Information on cuttage propagation of big sagebrush is particularly scarce. One of the earliest references to sagebrush propagation is by Taylor $(1927$, p. 84$)$, who indicated that Artemisia tridentata cuttings rooted to a lesser degree than $A$. abrotanum when short, twiggy cuttings were taken along with a short portion of main stem (a heel cutting) in July and August. Wallace and Romney (1972, p. 95) found that big sagebrush cuttings were easy to root when succulent, vigorous material from young plants was treated with $0.3 \%$ indolebutyric acid (IBA) and maintained in a mist chamber. Others have mentioned using big sagebrush rooted cuttings in their investigations but provided no clues as to how the material was propagated (Lunt, et al. 1973). We report here the results of three experiments conducted to define the influence of synthetic auxin rates, plant dormancy, and individual source plants on rooting performance of big sagebrush stem cuttings.

The authors are graduate student, and professor, Institute for Land Rehabilitation and Kange Science Department. Utah State University, Logan, I tah 84322.

Manuscript received April 2, 1978.

This study was conducted as a project of the Institute tor Land Rehabilitation, Utah State University, and was supported by funds from the White River Shale Project, Sun Energy Development Co.
Methods

\section{General Procedures}

This work relied on a basic procedure developed during 1975. The preliminary work and other relevant information were described by Alvarez-Cordero (1977).

Cuttings were prepared in the field from terminal and lateral twigs, with intact terminal buds. Hand clippers were used to take the material from the base of the previous season's growth. The cuttings, which ranged in length from 8 to $12 \mathrm{~cm}$ were treated and planted within 36 hours after collection.

Leaves and buds were removed from the basal portion of each cutting. The defoliated portion of each cutting was dipped in water and afterwards into a talc-base indolebutyric acid ${ }^{1}$ IBA mixture. Each cutting was lightly tapped to remove excess powder. Control cuttings were treated only with water. The basal portion of each cutting was than inserted into a peat pellet ${ }^{2}$ previously expanded with water.

A wooden frame covered with a clear-plastic film was built on top of a glasshouse bench to serve as a rooting chamber. Automatically regulated stem pipes under the bench provided uniform heating. Water spray applied daily insured adequate moisture conditions

The number of rooted cuttings in the treatment combinations were expressed as a percentage. These data were subjected to angular (inverse sine) transformation prior to analysis. The appropriate analysis of variance procedure, followed by Duncan's new multiple range test were applied to the data from the three experiments. Details of each experiment are described below.

\section{Response to IBA Concentration: Experiment 1}

To test the stimulative effect of IBA on sagebrush adventitious root production, Artemisia tridentata spp. vaseyana stem cuttings were treated with various concentrations of commercially available IBA. The source plants were randomly selected from a natural stand growing on gravelly soil in the mouth of Green Canyon, located about $6 \mathrm{~km}$ northeast of Logan, Utah. All sampled plants were growing within a $100-\mathrm{m}$ radius on an alluvial terrace. Approximately $30 \mathrm{~cm}$ of snow lay on the ground when the cuttings were obtained on February 3, 1976. One hundred cuttings were taken from each of four plants during the early morning hours.

All four plants were mature and dormant (inactive) at the time of cutting collection. Five treatments were applied in a randomized complete-block design: control (no IBA applied), $0.1 \%$ IBA, $0.3 \%$ IBA, $0.8 \%$ IBA, and $2.0 \%$ IBA. Twenty cuttings from each plant were assigned to cach treatment. All cuttings were identified as to their plant origin to assess the performance of each source plant. After planting, the cuttings were placed in plastic trays with drainage holes. The trays were then placed inside the clear-plastic enclosure.

Cuttings were kept in the rooting facility for $\mathbf{5 2}$ days. During the rooting period the daytime ambient temperature ranged from 20 to $23^{\circ} \mathrm{C}$. Night temperature was maintained above $13^{\circ} \mathrm{C}$.

\footnotetext{
Utilizing Hormodin No. 1,2,3, and 2.0\% IBA preparation sold by Merck Chemical Chemical Division, Merck \& Co., Inc., Rahway, N.Y. 07065, U.S.A.

- Jiffy No. 9 compressed and sterilized propagation pellets (ph 5.5 to 6.0 ) sold by the Porter Walton Company, 470 W. 600 So., Salt Lake City, Utah.
} 
Influence of Date of Collection on the Effectiveness of IBA Treatments: Experiment 2

A second experiment was designed to test the influence of plant dormancy on rooting of IBA-treated cuttings taken during the transition from dormancy to active growth. Source plants were Artemisia tridentata wyomingensis randomly selected from an area near the experimental revegetation site for two prototype oil shale lease tracts 6 $\mathrm{km}$ south of Bonanza, Utah. Twenty mature plants, uniform in size and vigor and exhibiting few or no signs of grazing damage on their stems, were permanently identified. The plants selected were located on moderately sloping terrain within an area of approximately 4.5 ha. The plant cover of the area was typical of the Atriplex confertifolia Torr. \& Frem. vegetation type described in the baseline vegetation study conducted on the tracts (VTN, 1977).

Cuttings were collected four times (March 26, April 10, April 24, and May 8) to encompass the approximate period from growth initiation (budshoot activation) to active vegetative growth at the end of spring. A randomized, complete-block design was used to assess the affects of a control treatment (no IBA), a low concentration $(0.3 \%$ IBA) and a high concentration ( $2.0 \%$ IB $\Lambda$ ) of synthetic auxin. A set of five different plants was assigned to each of the four sampling dates. At each date, 90 cuttings were taken from each plant and equally divided among the IBA treatments. Thus, five replicates of 30 cuttings were subjected to each treatment, at each sampling/date combination.

A fine mesh screen of galvanized metal was added to the rooting facility and the cutting-pellet units were placed directly on the screen instead of in plastic trays. The duration of the rooting period was set arbitrarily at 40 days. Air and peat pellet temperatures were monitored inside the rooting facility from March 26 to June 16, when the last sample of cuttings was evaluated. Peat pellet temperature averaged $19^{\circ} \mathrm{C}$ and air temperature averaged $23^{\circ} \mathrm{C}$. On sunny days, a more pronounced temperature increase occurred in air than in pellets. The number of sunny days during the rooting period of each of the four sampling groups of cuttings was approximately equal.

\section{Rootability Differences among Source Plants: Experiment 3}

Experiment 3 was designed to test the rootability of cuttings taken over a period of time from the same source plants. This experiment was carried out simultaneously with experiment 2 , using additional plants of subspecies $A$. wyomingensis randomly selected in the same locality. A randomized complete-block design was used to compare the performance of cuttings collected from five source plants four times (March 26, April 10, April 24, and May 8). Thirty cuttings were taken from each source plant at every sampling. All cuttings were treated with $2.0 \%$ IBA and placed with those of Experiment 2 for an identical rooting period.

\section{Results and Discussion}

Three factors proved crucial to the successful propagation of big sagebrush stem cuttings: (1) stimulation of adventitious root production with IBA treatments, (2) date of collecting cuttings,

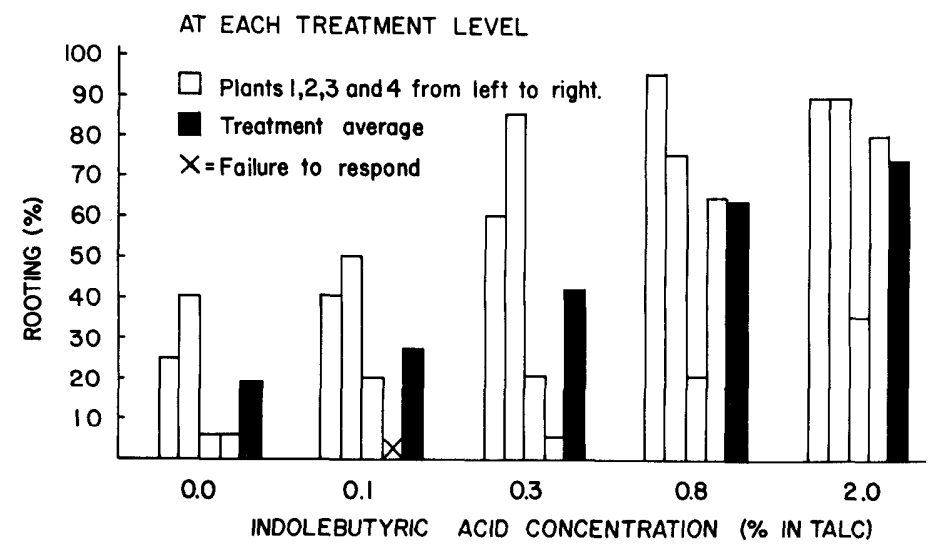

Fig. 1. Rooting response of cuttings of four plants of big sagebrush (ssp. vaseyana) as affected by five levels of chemical treatment.
(3) and inherent rootability of the stock plant being propagated.

In general, rooting increased as a function of the increase in concentration of IBA applied (Fig. 1). The rooting of subspecics vaseyana cuttings treated with $0.8 \%$ IBA was significantly higher than was observed in untreated cuttings or in those receiving $0.1 \%$ IBA. The highest level of IBA $(2.0 \%)$ stimulated significantly more rooting than occurred in control cuttings and more than that of cuttings given 0.1 and $0.3 \%$ IBA. The effects of the two highest IBA levels did not differ statistically.

The results obtained with subspecies wyomingensis cuttings indicated that $2.0 \%$ IBA was more effective than $0.3 \%$ IBA in rooting cuttings obtained in the spring. All cuttings not receiving IBA failed to produce adventitious roots, whereas those given the low level of auxin exhibited a significant amount of rooting. Cuttings treated with the high auxin level exhibited a significantly more vigorous rooting performance ( $21 \%$ average rooting over all spring dates) than those given the low IBA concentration. Apparently $2.0 \%$ IBA was more effective than $0.3 \%$ IBA in overcoming the low rootability of cuttings from certain source plants (Fig. 2). Cuttings from every source plant

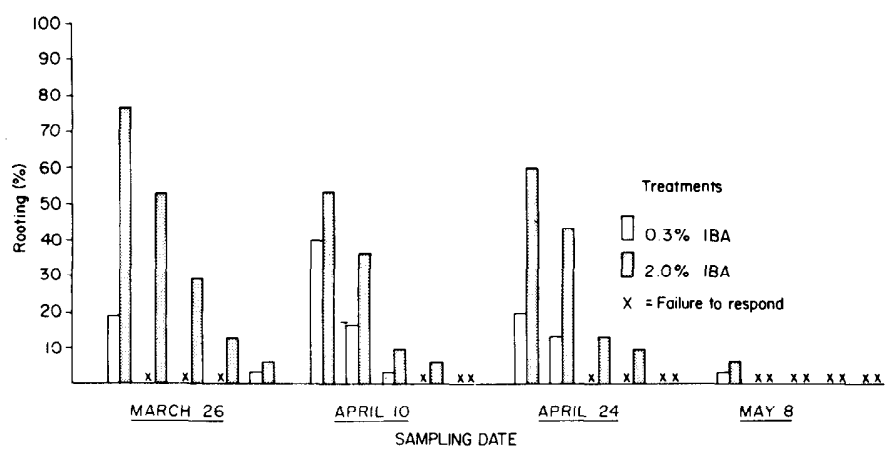

Fig. 2. Rooting of big sagebrush (ssp. wyomingensis) stem cuttings at four spring sampling dates in response to a low and a high concentration of indolebutyric acid. (Each bar shows percentage rooting of 30 cuttings).

that responded to the low IBA level exhibited their highest performance with the high IBA treatment. In addition, the high treatment level was effective on six of the twelve source plants whose cuttings failed to respond to the low level of IBA.

There were no significant $(P=0.05)$ interactions between IBA treatments and spring dates of collecting cuttings. All

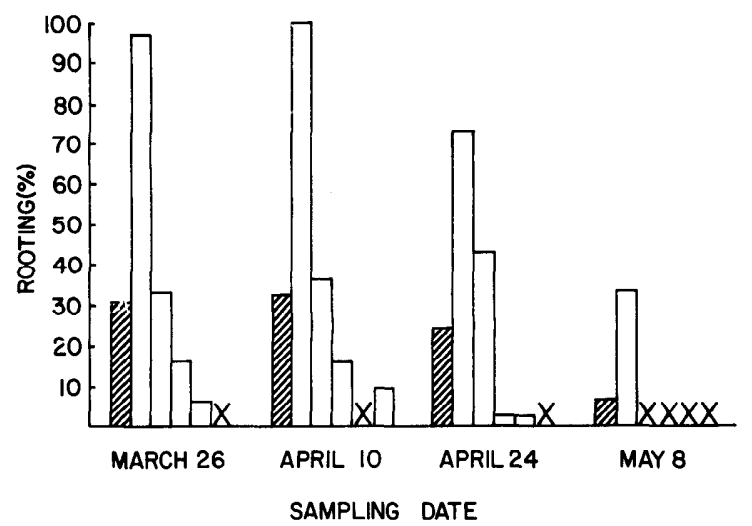

AT EACH DATE

Left to right, percentage rooting of 30 cuttings from plants $2,5,3,1$, and 4 ( $X=$ failure to respond)

Vampling date average

Fig. 3. Rooting performance of big sagebrush (ssp. wyomingensis) cuttings taken from five plants at four periods of spring growth. All cuttings were given $2.0 \%$ indolebutyric acid. 
cuttings of $A$. wyomingensis subspecies that did not receive an IBA treatment failed to root. Ability to respond to the IBA treatment was practically nonexistent in the cuttings taken in May (Fig. 3). This indicated that IBA could not compensate for the loss of rootability that occurs as plants enter the active period of vegetative growth.

The decline in rooting ability observed as the growing season advanced may have been related to developments in the sagebrush stems that signal the internal expansion of an interxylary cork cambium (ICC) layer typical of many Artemisia species (Diettert 1938; Moss 1940). During the latter part of April, we observed vertical hairline fissures appearing on some stems of some of the subspecies $A$. wyomingensis plants of the stand sampled. By the last cutting harvest on May 8, these fissures had become more pronounced and generalized in the stems, in many cases being up to $2 \mathrm{~mm}$ wide and ranging from 10 to $20 \mathrm{~mm}$ in length. The observed splitting corroborates the occurrence of radial increases in the stems mentioned by Daubenmire (1975). Further work on this observation in relation to rooting appears warranted.

Marked differences in rooting occurred among the five plants of subspecies wyomingensis (Fig. 3). The rooting of cuttings obtained from plant 2 was significantly higher than that of cuttings from the other four plants. Similarly, cuttings from two of the four plants of subspecies vaseyana tested in February averaged above $60 \%$ rooting (plants 1 and 2 ) and had significantly better rooting than did cuttings from the other two plants (Fig. 1). The basic cause of rootability variations among big sagebrush plants has not yet been determined but it is probably genetic in nature and results from morphological and physiological differences. No observable differences in appearance were noted among plants with high and low rooting abilities in our studies.

\section{Conclusions}

Cuttings of big sagebrush exhibited marked seasonality in their ability to produce adventitious roots. Cuttings obtained in the winter during the quiescence-dormancy stage showed more rooting activity than those collected from actively growing plants.

The indication that auxin treatments were ineffective against the factors determining low seasonal rooting (Nanda 1970) was verified in this investigation. However, the use of IBA is recommended to increase rooting performance of winter and early spring cuttings.

It is crucial to identify plant sources that will give cuttings of high rootability. Evaluation of experimental results with sagebrush cuttings should be made in relation to the known rootability of source plants used.

\section{Literature Cited}

Alvarez-Cordero, E. 1977. Stem cutting propagation of big sagebrush (Artemisia tridentata Nutt.). MS thesis, Utah State University, Logan. 122 p.

Daubenmire, R. 1975. Ecology of Artemisia tridentata subsp. tridentata in the state of Washington. Northwest Sci. 49:24-35.

Diettert, R.A. 1938. The morphology of Artemisia tridentata Nutt. Lloydia 1:3-74.

Lunt, O.R., J. Letey, and S.B. Clark. 1973. Oxygen requirements for root growth in three species of desert shrubs. Ecology 54:1356-1362.

Moss, E.H. 1940. Interxylary cork in Artemisia with a reference to its taxonomic significance. Amer. J. of Bot. 27:762-768.

Nanda, K.K. 1970. Investigation on the use of auxins in vegetative reproduction of forest plants. Final Report of PL 480 Research Project, A7-FS11 (FG-In-255). August 1965 to August 1970. Changigarh-14, India. 215 p.

Taylor, G.C. 1927. The propagation of hardy trees and shrubs. Dulau \& Co., Ltd., London. $120 \mathrm{p}$.

VTN Colorado Inc. 1977. Final Environment Baseline Report Federal Prototype Oil Shale Leasing Program, Tracts Ua and Ub, Utah. Final Environmental Bascline Report Federal prototype oil shale Leasing Program, Tracts Ua and Ub, Utah. Section IV Vegetation Biological Resources, Section IV-2IV-78. White River Shale Project. Vernal, Utah.

Wallace, A., and E.M. Romney. 1972. Radioecology and ecophysiology of desert plants at the Nevada test site. U.S. Atomic Energy Commission. Division of Biology and Medicine (TID-25954). Nat. Tech. Info. Serv., U.S Dep. Commerce, Springfield, Va. 405 p. 